\title{
Implementasi Manajemen Promosi Kbih dalam Meningkatkan Minat Bimbingan Jamaah Haji
}

\author{
Saepurrahmat ${ }^{1 *}$, Ruhiyat $1^{1}$, Asep Iwan Setiawan $2^{2}$ \\ 123Jurusan Manajemen Dakwah, Fakultas Dakwah dan Komunikasi, UIN Sunan Gunung Djati, \\ Bandung \\ *Email : saepurrabmat@student.uinsgd.ac.id
}

\begin{abstract}
ABSTRAK
Penelitian ini bertujuan untuk mengetahui bagaimana proses promosi yang dilakukan oleh $\mathrm{KBIH}$ Assyakur melalui impelementasi dari bauran promosi periklanan, penjulan personal dan dari mulut ke mulut dalam meningkatkan minat jamaah untuk melakukan bimbingan di KBIH Assyakur. Metode yang digunakan dalam penelitian ini yaitu kualitatif deskriptif adalah berupa penelitian dengan metode penelitian studi kasus (case study). Penelitian ini memusatkan diri secara intensif pada satu obyek tertentu yang mempelajarinya sebagai suatu kasus. Dimana Subjek dalam penelitian ini adalah KBIH Assyakur yang didalamnya terdapat pengurus, pengelola, pengguna jasa, yang dapat dijadikan sumber informasi. Hasil penelitian dan analisis data manajemen promosi yang dilakukan oleh KBIH Assyakur melalui periklanan, dengan media cetak (brosur), media internet (website), media sosial (facebook). Penjualan perorangan dan promosi dari mulut ke mulut yang dilakukan oleh alumni-alumni yang sudah pernah dibimbing di KBIH Assyakur, promosi dengan menggunan dari mulut ke mulut adalah promosi yang paling effektif yang dilakukan oleh $\mathrm{KBIH} \mathrm{KBIH}$ Assyakur Batununggal Kota Bandung.
\end{abstract}

Kata Kunci : Manajemen; Manajemen Promosi; Minat.

\section{ABSTRACT}

This study aims to determine the promotion process carried out by KBIH Assyakur through efforts from advertising, personal sales and from the mouth into increasing interest in conducting guidance in KBIH Assyakur. The method used in this study is qualitative descriptive namely case studies with case studies (case studies). This research focuses on one particular side that studies it as a case. Where the subjects in this study are KBIH Assyakur in which there are administrators, managers, which can be used as information. The results of research and analysis of promotion management data conducted by KBIH Assyakur through advertising, with print media (brochures), internet media (website), social media (Facebook). Sales of individuals and word of mouth promotions conducted by alumni who have been 
Saepurrahmat, Ruhiyat, A.I. Setiawan

mentored at KBIH Assyakur, promotion by word of mouth is the most effective promotion conducted by KBIH KBIH Assyakur Batununggal in Bandung.

Keywords: Management; Promotion Management; Interest

\section{PENDAHULUAN}

Yayasan Assyakur adalah sebuah yayasan yang bergerak dalam bidang sosial, pendidikan, haji dan dakwah. Semua aktivitasnya berjalan karena Allah semata tidak untuk mencari keuntungan material (non profit orinted). Yayasan ini telah terdaftar pada akta notaris tanggal 10 Pebruari 1993. Sedangkan KBIH Assyakur sendiri didirikan pada tahun 2000, Menurut H. Adang Nurdin KBIH Assyakur pada awal tahun hanya bisa memberangkatkan jamaah haji 14, tahun 2001 ada 35 jamaah haji, tahun 2002 ada 35 jamaah haji dan tahun 2004 ada 35 jamaah haji, peningkatan terbesar yaitu terjadi di tahun 2017 ada 143 jamaah haji yang diberangatkan ke tanah suci. Setelah berjalan beberapa tahun KBIH semakin berkembang dan banyak jamaah haji yang mendaftar untuk melakukan bimbingan di KBIH Assyakur, peningkatan tersebut tidak terlepas karena mulai membaiknya promosi yang dilakukan oleh KBIH dengan menggunakan promosi dari mulut ke mulut walaupun dianggap promosi yang tradisonal namun cara ini masih cukup ampuh untuk meyakinkan konsumen.

$\mathrm{KBIH}$ Assyakur mempunyai keunggulan tersendiri dalam mempromosikan KIBH nya, promosi yang dilakukan menggunakan media cetak yaitu brosur, media online yaitu Website dan Facebook, serta promosi dari mulut ke mulut (word of mouth).

Brosur mempunyai keunggulan yaitu sederhana, menarik, sehingga konsumen bisa langsung memahami maksud yang disampaikan. Website dan Facebook salah satu situs jejaring sosial yang banyak dipakai oleh masyarakat sehingga promosi menggunakan facebook bisa lebih mudah, KBIH Assyakur memanfaatkan facebook yaitu membuat fanspage facebook untuk menarik jamaah haji yang akan mendaftar di KBIH.

Promosi dari mulut ke mulut (word of mouth) promosi ini memberikan banyak kemudahan dalam membantu memasarkan sebuah produk atau jasa dengan kekuatan rekomendasi pribadi dari orang terdekat dan dapat meningkatkan kepercayaan konsumen, KBIH Assyakur menggunakan strategi ini kepada alumni-alumni jamaah haji yang telah dibimbing di KBIH agar bisa bersilaturrahim sehingga alumni bisa saling berkomunikasi dengan sendirinya para alumni melalukan promosi dari mulut ke mulut.

Kelompok Bimbingan Ibadah Haji (KBIH) adalah Lembaga dalam bentuk organisasi yang berbadan hukum dan kedudukannya sebagai mitra kerja pemerintah dalam melakukan pembinaan dan membimbing jamaah haji, berdasarkan undang-undang republik indonesia Nomor 13 tahun 2008 Tentang Penyelenggaraan Ibadah Haji, pembinaan terhadap jamaah haji mutlak dilakukan. 
Hal ini untuk mewujudkan kemandirian jamaah haji dalam melaksanakan ibadah haji sejak pendaftaran hingga pelaksanaan ibadah haji. Untuk membina dan membimbing jamaah haji penyelenggara haji dalam hal ini departemen agama harus melibatkan unsur masyarakat.

Fenomena meningkatnya jumlah jamaah haji di indonesia dan selalu menempati urutan paling atas dibanding negara lain, yaitu lebih dari dua ratus ribu pertahunnya. mengingat begitu dengan potensi $\mathrm{KBIH}$ yang demikian besar dan strategis serta merupakan lembaga yang bergerak di bidang jasa. Dimana usaha jasa ini yang ditanganinya adalah jasa penyelengaraan ibadah haji dalam upaya meningkatkan pelayanan kepada jamaah haji. Kemudian lahir Kelompok Bimbingan Ibadah Haji (KBIH), saat ini terdapat sekitar $45 \mathrm{KBIH}$ di kota bandung yang telah terdaftar dan terakreditasi oleh Kementrian Agama untuk memberikan bimbingan manasik kepada para calon jamaah haji.

Sebanyak 2.474 jamaah haji kota bandung di tahun 2017 menurut Kementerian Agama kota bandung yang telah diberangkatkan ke tanah suci, dengan jamaah haji sebanyak itu calon jamaah haji masih banyak yang awam tentang rukun haji, yaitu suatu kegiatan yang harus dilakukan dalam melakukan ibadah haji, jika tidak dikerjakan maka hajinya tidak sah atau batal oleh karenanya calon jamaah haji harus terlebih dahulu melakukan bimbingan agar bisa memahami dan melaksanakan rukun dan wajib haji, KBIH berperan penting dalam memberikan bimbingan tehnis maupun manasik calon jamaah haji membimbing jemaah calaon haji (pra-haji dan paska haji). Di dalam KBIH calon jamaah haji akan diberikan informasi secara detail tentang fiqih haji yang sangat banyak. Calon jamaah akan diberikan teori maupun praktek bagaimana melakukan ihram, tawaf, sai, lempar jumrah, dan sebagainya. Selain itu juga disampaikan praktek ibadah tersebut dan simulasi keberangkatan calon jamaah haji dari satu area ke area lain.

Tidak sedikit kompetisi diantara KBIH terjadi agar KBIH bisa menambah jumlah jamaah yang dibimbing dan bisa menjadi KBIH predikat terbaik. Oleh karena itu promosi di butuhkan guna mendapat predikat KBIH terbaik dan menarik para calon jamaah haji untuk melakukan bimbingan di KBIH, namun menarik minat jamaah untuk melakukan bimbingan di KBIH tidaklah mudah karena banyaknya $\mathrm{KBIH}$ yang lain.

\section{LANDASAN TEORITIS}

Teori yang akan dijadikan landasan dalam penelitian ini adalah teori manajemen, manajemen promosi, pengertian tentang $\mathrm{KBIH}$ dan Jemaah Haji. Definisi manajemen menurut Mary Parker Follett di kutip dari T. Hani Handoko, mendefinisikan manajemen sebagai seni dalam menyelesaikan pekerjaan melalui orang lain. Definsi ini mengandung arti bahwa para manajer mencapai tujuan- 
tujuan oraganisasi melalui pengaturan orang-orang lain untuk melaksanakan berbagai tugas yang mungkin diperlukan, atau berarti dengan tidak melakukan tugas-tugas itu sendiri. Definisi manajemen menurut Stoner dikutip dari (Handoko, 2009:8).

Unsur-unsur manajemen terdiri dari 6 unsur yang disingkat dengan $6 \mathrm{M}$, yaitu man, money, methods, materials, machines, market. Manajemen promosi merupakan kegiatan untuk mengarahkan serta membimbing dalam kegiatan memperkenalkan produk, meyakinkan dan mengingatkan kembali manfaat produk tersebut kepada konsumen dengan harapan mereka terjebak hatinya dengan sukarela menjadi mitranya (Sutoyo, 1981 :24).

Sedangkan Philip mendefinisikan manajemen promosi sebagai penganalisaan, pelaksanaan dan pengawasan program-program yang ditujukan untuk menarik sebagai mitra dengan untuk mencapai tujuan organisasi (Kotler, 1996: 38).

Promosi adalah bagian dan proses strategi pemasaran sebagai cara untuk berkomunikasi dengan pasar, dengan menggunakan komposisi bauran promosi (promotional mix). Bauran promosi merupakan gabungan arus informasi secara menyeluruh dan hanya dilakukan oleh satu organisasi atau individu tertentu. Ini berbeda dengan komunikasi pemasaran yang bertujuan untuk memuaskan semua pihak. Semua pihak yang terlibat dalam proses komunikasi pemasaran melakukan cara yang sama yaitu mendengarkan, bereaksi dan berbicara sampai tercipta hubungan pertukaran yang memuaskan.

Tujuan utama dari promosi adalah menginformasikan, mempengaruhi dan membujuk, serta mengingatkan pelanggan sasaran tentang perusahaan dan bauran pemasarannya.

Secara singkat promosi berkaitan dengan upaya untuk mengarahkan seseorang agar dapat mengenal produk suatu perusahaan, memahaminya, berubah sikap, menyukai, yakin, dan kemudian akhirnya membeli dan selalu ingat akan produk tersebut.

Kelompok bimbingan ibadah haji (KBIH) merupakan salah satu organisasi dakwah yang bertugas untuk membantu proses pelayanan ibadah haji di Indonesia. KBIH merupakan lembaga atau yayasan sosial islam dan pemerintah bergerak di bidang bimbingan manasik haji terhadap calon jamaah haji baik selama dalam pembekalan di tanah air maupun pada saat pelaksanaan ibadah haji di Arab Saudi. KBIH sebagai lembaga sosial keagamaan (non pemerintah) telah memiliki legalitas pembimbing melalui undang-undang (Aziz, 2007: 17).

Dalam buku pintar penyelenggaraan ibadah haji $(\mathrm{PIH}), \mathrm{KBIH}$ merupakan lembaga social keagamaan yang telah mendapatkan izin Kemetrian Agama untuk melaksanakan bimbingan terhadap jama'ah haji (Kementerian Agama Republik Indonesia, 2012: 2).

Pada dasarnya KBIH untuk membantu bimbingan jamaah haji di tanah air 
(Depag RI, 1998:31). KBIH adalah lembaga yayasan sosial Islam yang bergerak di bidang manasik haji terhadap calon jamaah haji baik selama pembekalan di tanah air maupun pada saat ibadah haji di Arab Saudi.

$\mathrm{KBIH}$ sebagai sebuah organisasi sosial kemasyarakatan Islam merupakan organisasi underbow dari satu organisasi induk yang berbadan hukum dan mempunyai program kerja membimbing dan membina calon jamaah haji (Kep. Dirjen No 348/2003 tentang petunjuk pelaksanaan Ibadah Haji dan Umrah pasal 13,17,19,20, dan 24).

Fungsi KBIH dalam pembimbing meliputi: Penyelenggara atau pelaksana bimbingan ibadah haji tambahan di tanah air sebagai bimbingan pembekalan; Penyelenggara atau pelaksana bimbingan lapangan di Arab Saudi; Pelayan, konsultan dan sumber informasi perhajian; Motivator bagi anggota jamaahnya terutama dalam hal-hal penguasaan ilmu manasik, keabsahan, dan kesempurnaan ibadah (Depag RI, 2008).

A Chuaini Saleh menyatakan bahwa sejak lahir akhir tahun 90-an, jumlah KBIH semakin menjamur dan seiring dengan itu orientasi bisnisnya juga kian menonjol. Berkenaan dengan itu, maka pemerintah melakukan berbagai pengaturan agar kegiatan-kegiatan KBIH tidak merugikan masyarakat yang akan melaksanakan ibadah haji. Pemerintah menjadikan pihak swasta (khususnya $\mathrm{KBIH})$ tersebut sebagai mitra dengan memberikan wewenang dalam bidang bimbingan ibadah, bukan dalam operasional teknis penyelenggaraan ibadah haji. Dengan tugas dan wewenang yang tegas tersebut, bimbingan; pelayanan; dan perlindungan terhadap jamaah haji dapat dilakukan secara optimal (Depag, 2008: 63).

Metode Bimbingan KBIH adalah: Penataran Calon Jamaah Haji (Pembimbingan Paket); Ceramah; Sarasehan; Pengajian; Home Visit; Konsultasi; Peragaan.

Minat adalah suatu keadaan dimana seseorang mempunyai perhatian terhadap sesuatu dan disertai keinginan untuk mengetahui dan mempelajari maupun membuktikan lebih lanjut. sedangkan menurut Witherington minat adalah kesadaran seseorang terhadap suatu objek, seseorang, situasi maupun suatu soal tertentu yang menyangkut dengan dirinya atau dipandang sebagai sesuatu yang sadar.

Minat berperilaku adalah keinginan (Minat) seseorang untuk melakukan perilaku diprediksi oleh sikapnya terhadap perilakunya dan bagaimana dia berpikir orang lain akan menilainya jika dia melakukan perilaku tersebut (Jogiyanto, 2007: 20). Minat adalah kecenderungan jiwa yang tetap untuk memperhatikan dan mengenang beberapa aktivitas atau kegiatan. Jadi apabila seseorang berminat untuk memperhatikan suatu aktivitas dan melakukan aktivitas yang dilakukan pasti dengan dilandasi rasa senang dalam melakukannya. 
Jika menimbulkan rasa senang, maka seseorang di masa yang akan datang akan secara terus - menerus ingin menggunakannya (Slameto, 2003: 30).

Fungsi Minat sangat berhubungan erat dengan perasaan dan pikiran. Manusia akan memberikan suatu penilaian, menentukan sesudah memilih pilihan yang diinginkan dan secara langsung mengambil suatu keputusan. Minat merupakan kecenderungan hati yang tinggi terhadap sesuatu yang timbul karena kebutuhan, yang dirasa atau tidak dirasakan atau keinginan hal tertentu (Saraswati, 2013).

Minat tidak dibawa sejak lahir, melainkan diperoleh kemudian. Minat terhadap sesuatu merupakan hasil belajar dan menyokong belajar selanjutnya. Hal ini menggambarkan bahwa minat dapat ditumbuhkan dan dikembangkan. (Slameto, 2003: 32).

Seseorang dikatakan berminat terhadap sesuatu bila individu itu memiliki beberapa unsur antara lain: Perhatian; Kesenangan; Kemauan.

Jamaah haji adalah warga negara Indonesia yang beragama Islam dan telah mendaftarkan diri untuk menunaikan Ibadah Haji sesuai dengan persyaratan yang ditetapkan (UU No.13 Tahun 2008: 2). Jamaah haji adalah seseorang atau sekelompok umat Islam yang akan menunaikan ibadah haji ke tanah suci dan memiliki kemampuan untuk melakukan pembayaran, seorang customer yang menginginkan pelayanan prima dan mempunyai kebebasan untuk menentukan apa yang dipilihnya sesuai dengan kemampuan dan tingkat pelayanan yang dikehendaki dan juga memenuhi rukun, syarat, wajib, sunah dan semua persyaratan untuk menunaikan ibadah haji (Nidjam, 2004: 11).

Jamaah haji adalah seorang muslim yang memiliki niat menunaikan ibadah haji dan kemampuan secara fisik untuk menjalani ritual peribadatan dan menyediakan pembiayaan perjalanan. Dapat disimpulkan bahwa jamaah haji adalah jamaah yang sedang menunaikan ibadah haji atau telah selesai menunaikan ibadah haji pada tahun bersangkutan (baik yang mengikuti Kelompok Bimbingan Ibadah Haji (KBIH) maupun Pemerintah) (Aziz, 2007: 13).

\section{HASIL DAN PEMBAHASAN}

Penelitian ini dilakukan di KBIH Assyakur Jl. Soekarno Hatta No. 464, Batununggal, Bandung Kidul, Kota Bandung, Jawa Barat 40266. pengambilan lokasi di daerah tersebut mengingat besarnya kemungkinan penelitian dapat dilaksanakan yaitu dengan melihat data-data yang dibutuhkan dalam penelitian ini tersedia dan untuk mengumpulkan data-data juga tidak terlalu sulit.

Hasil penelitian ini menemukan tentang manajemen organisasi pada $\mathrm{KBIH}$ Assyakur dan manajemen promosi KBIH Assyakur. 


\section{Manajemen Organisasi pada KBIH Assyakur}

KBIH Assyakur merupakan organisasi yang mempunyai tujuan serta berharap tujuan organisasi bisa tercapai secara efektif dan efisien. Sehingga bisa meningkatkan jumlah jamaah pendaftar pada Kelompok Bimbingan Ibadah Haji $(\mathrm{KBIH})$ setiap tahunnya merupakan suatu keharusan. Untuk mencapai tujuan organisasi yang efektif dan efisien, KBIH Assyakur menyusun rencana program kerja yang akan dijalankan.

Adapun program kerja dari KBIH Assyakur adalah sebagai berikut: Pertama, Kelompok Bimbingan Ibadah Haji (KBIH) Assyakur pada awal berdiri tahun $2000 \mathrm{KBIH}$ Assyakur tidak melakukan perekrutan jamaah haji karena banyak masyarakat yang ingin mendaftar ke KBIH, namun pada tahun-tahun berikutnya jamaah KBIH Assyakur melakukan promosi guna merekrut para calon jamaah mengingat sekarang sudah banyaknya berdiri KBIH di Kota bandung. Promosi yang dilakukan KBIH Assyakur sendiri menggunakan media cetak yaitu brosur yang di berikan kepada alumni-alumni jamaah KBIH Assyakur.

Kedua, KBIH Assyakur mengantar dan mendampingi calon jamaah haji dalam menyetorkan Biaya Perjalanan Ibadah Haji (BPIH), ke bank yang ditunjuk pemerintah, penyelesaian administrasi ke kantor Kementerian Agama, dan pemeriksaan kesehatan di Puskesmas. Dengan harapan para calon jamaah akan lebih mudah dalam proses pendaftaran.

Bimbingan Manasik Haji (di Tanah Air). KBIH Assyakur memberikan pelajaran manasik haji kepada jamaahnya secara klasikal, maupun individual. Pemberian bimbingan manasik oleh KBIH dijadwalkan materi apa yang akan disampaikan, siapa yang memberikan bimbingan dan waktu pelaksanaan. Materi yang disampaikan yaitu materi pokok diantaranya Aqidah, Syari'ah, Akhlaq, Kesehatan, Geografidan kebudayaan bangsa arab, Bahasa arab sehari-hari, Ziarah dan rihlah islami, Seputar pengamalan menarik jamaah haji, tata tertib perjalanan haji, doa-doa. Adapun materi khusus diantaranya Kaidah-kaidah haji dan umrah, Permasalahan haji dan umrah, Hal-hal yang merusak haji dan umrah, Melestarikan kemabruran haji dan segala sesuatu yang berkaitan dengan ibadah haji.

Bimbingan Ibadah haji (di Tanah Suci). Jamaah yang mengikuti KBIH Assyakur, selain mendapatkan bimbingan manasik sebelum keberangkatan juga mendapatkan bimbingan di Tanah Suci. Setiap tahunnya KBIH Assyakur selalu menugaskan perwakilan dari pengurus untuk menjadi pembimbing di Tanah Suci.

Bimbingan di Tanah Air (pasca ibadah haji). Selain pembimbingan di 
Saepurrahmat, Ruhiyat, A.I. Setiawan

Tanah Air dan di Tanah Suci, KBIH Assyakur juga memberikan bimbingan pasca ibadah haji. Pembimbingan ini bertujuan untuk menjaga kemabruran jamaah setelah melaksanakan ibadah haji.

Perlengkapan haji. Ibadah haji merupakan ibadah yang memerlukan persiapan yang matang, selain persiapan fisik dan mental. Perlengkapan haji juga harus disiapkan sebaik mungkin. Untuk memudahkan para jamaah dalam mempersiapkan perlengkapan, maka KBIH melayani jamaah yang akan membeli perlengkapan haji maupun memesan/belanja oleh-oleh seperti air zam-zam, sajadah, tasbih, buah kurma, dll dengan harga standar (dokumentasi dan wawancara dengan H. Adang Nurdin, pengurus KBIH Assyakur, 25/05/2018).

Penerapan Fungsi Pengorganisasian. Pengorganisasian merupakan fungsi manajemen yang bertujuan untuk menentukan tugas ataupun fungsi dari masingmasing unit dari struktur organisasi. Pada KBIH Assyakur tersusun struktur organisasi dan pembagian tugas pada bidangnya masing-masing. Pembagian tugas ini berfungsi agar semua kegiatan yang direncanakan dapat terlaksana dengan efektif dan efisien. Dengan penerapan fungsi pengorganisasian, para pengurus dapat memahami dan menjalankan tugas masing-masing bagian yang telah ditentukan. Pada KBIH Assyakur bagian dari struktur organisasinya adalah sebagai berikut: Pembina; Ketua umum; Wakil ketua; Sekretaris; Bendahara; Bidang Pendidikan; Bidang haji $(\mathrm{KBIH})$; Bidang Sosial; Bidang Budaya dan kemasyarakatan.

Penerapan Fungsi Penggerakan. Penggerakan (actuating) merupakan fungsi yang ketiga dari fungsi manajemen, setelah fungsi perencanaan dan pengorganisasian. Suatu organisasi harus menyusun rencana yang akan dilakukan dan mengorganisasikan rencana tersebut. Namun, untuk menunjukkan hasil yang dicapai, suatu organisasi harus melakukan action atau tindakan. Dengan fungsi penggerakan ini, semua yang telah ada dalam perencanaan dan pengorganisasian bisa terlaksana. Implementasi dari fungsi perencanaan dan pengorganisasian KBIH Assyakur adalah sebagai berikut:

Pertama, perekrutan jamaah merupakan salah satu hal yang terpenting dalam kegiatan KBIH Assyakur. Dalam perekrutan jamaah, semua pengurus ikut andil. Selain itu, para jamaah yang pernah ikut bimbingan dengan KBIH Assyakur ikut andil dalam perekrutan jamaah dengan memberikan informasiinformasi tentang KBIH Assyakur. Para jamaah merasa puas dengan bimbingan yang telah diberikan KBIH Assyakur sehngga mereka mengajak saudara-saudara di sekitar mereka untuk ikut menjadi jamaah KBIH Assyakur.

Kedua, aplikasi Bimbingan Manasik Haji (di Tanah Air) Bimbingan yang dilakukan KBIH Assyakur di Tanah Air dilaksanakan secara berkesinambungan. Materi-materi yang disampaikan akan menjadi bekal bagi calon jamaah haji dalam menjalankan ibadah haji. Adapun jadwal pelaksanaan bimbingan manasik KBIH Assyakur Tahun 2018 adalah sebagai berikut: 
Tabel 1.

Jadwal Manasik Haji

\begin{tabular}{|c|c|c|c|}
\hline $\begin{array}{l}\text { TANG } \\
\text { GAL }\end{array}$ & PUKUL & POKOK BAHASAN & PEMATERI \\
\hline 7-Jan-18 & $\begin{array}{l}07.30- \\
09.15\end{array}$ & Pra Manasik I & $\begin{array}{l}\text { Drs. KH. A. Yusuf Abd. } \\
\text { Kadir, MM }\end{array}$ \\
\hline $\begin{array}{l}14-J a n- \\
18\end{array}$ & $\begin{array}{l}07.30- \\
09.15\end{array}$ & Pra Manasik I & $\begin{array}{l}\text { Dr. H. Ahmad Syamsir, } \\
\text { M.Si }\end{array}$ \\
\hline $\begin{array}{l}21-J a n- \\
18\end{array}$ & $\begin{array}{l}07.30- \\
09.15\end{array}$ & Pra Manasik II & $\begin{array}{l}\text { Drs. KH. A. Yusuf Abd. } \\
\text { Kadir, MM }\end{array}$ \\
\hline $\begin{array}{l}28-J a n- \\
18\end{array}$ & $\begin{array}{l}07.30- \\
09.15\end{array}$ & Pra Manasik II & $\begin{array}{l}\text { Dr. H. Ahmad Syamsir, } \\
\text { M.Si }\end{array}$ \\
\hline \multirow{2}{*}{ 4-Feb-18 } & $\begin{array}{l}07.30- \\
09.15\end{array}$ & Pembukaan Manasik Haji Intensif & $\begin{array}{l}\text { Kepala Kemenag Kota } \\
\text { Bandung }\end{array}$ \\
\hline & $\begin{array}{l}09.30- \\
11.00\end{array}$ & $\begin{array}{l}\text { Kebijakan Pemerintah mengenai } \\
\text { Pelaksanaan Haji }\end{array}$ & Kepala Seksi Urusan Haji \\
\hline $\begin{array}{l}11-\text { Feb- } \\
18\end{array}$ & $\begin{array}{l}09.00- \\
11.00\end{array}$ & Kajian Islam Bulanan & $\begin{array}{l}\text { H. Nur Ihsan Jundullah, } \\
\text { Lc }\end{array}$ \\
\hline $\begin{array}{l}18-\mathrm{Feb}- \\
18\end{array}$ & $\begin{array}{l}07.30- \\
10.30\end{array}$ & Aqidah Haji dan Motivasi Ibadah & $\begin{array}{l}\text { Dr. H. Ahmad Sarbini, } \\
\text { M.Ag }\end{array}$ \\
\hline $\begin{array}{l}25-\text { Feb- } \\
18\end{array}$ & $\begin{array}{l}07.30- \\
10.30\end{array}$ & Pengantar Budaya, Sosial bangsa Arab & $\begin{array}{l}\text { Drs. KH. A. Yusuf Abd. } \\
\text { Kadir, MM }\end{array}$ \\
\hline $\begin{array}{l}4-\mathrm{Mar}- \\
18\end{array}$ & $\begin{array}{l}07.30- \\
11.00\end{array}$ & $\begin{array}{l}\text { Perjalanan Umrah I (Sunat, Wajib, Rukun } \\
\text { dan larangan) }\end{array}$ & $\begin{array}{l}\text { Dr. H. Ahmad Syamsir, } \\
\text { M.Si }\end{array}$ \\
\hline $\begin{array}{l}\text { 15-Mar- } \\
18\end{array}$ & $\begin{array}{l}07.00- \\
09.00\end{array}$ & $\begin{array}{l}\text { Latihan Tawaf dan Sai di Lotte Mart, Jl. } \\
\text { Soekarno-Hatta }\end{array}$ & Pengurus Assyakur \\
\hline $\begin{array}{l}18 \text {-Mar- } \\
18\end{array}$ & $\begin{array}{l}07.30- \\
11.00\end{array}$ & $\begin{array}{l}\text { Sejarah dan Tempat-tempat Ziarah } \\
\text { Mekah, Madinah }\end{array}$ & H. Deden Hidayat, M.Ag \\
\hline $\begin{array}{l}25-\text { Mar- } \\
18\end{array}$ & $\begin{array}{l}07.30- \\
11.00\end{array}$ & Perjalanan Umrah II (simulasi) & $\begin{array}{l}\text { Dr. H. Ahmad Syamsir, } \\
\text { M.Si }\end{array}$ \\
\hline 1-Apr-18 & $\begin{array}{l}07.30- \\
09.15\end{array}$ & Proses Perjalanan Ibadah Haji (I) & $\begin{array}{l}\text { Dr. H. Ahmad Syamsir, } \\
\text { M.Si }\end{array}$ \\
\hline 8-Apr-18 & $\begin{array}{l}07.30- \\
09.15\end{array}$ & Pengantar Hikmah Haji dan Bazaar & $\begin{array}{l}\text { Drs. H. Yusuf Abd. Kadir, } \\
\text { MM }\end{array}$ \\
\hline
\end{tabular}

Tadbir: Jurnal Manajemen Dakwah Vol. 2 No. 3 (2017) 247-266 


\begin{tabular}{|c|c|c|c|}
\hline $\begin{array}{l}12-A p r- \\
18\end{array}$ & $\begin{array}{l}07.00- \\
09.00\end{array}$ & $\begin{array}{l}\text { Latihan Tawaf dan Sai di Lotte Mart, Jl. } \\
\text { Soekarno-Hatta }\end{array}$ & Pengurus Assyakur \\
\hline \multirow{2}{*}{$\begin{array}{l}\text { 15-Apr- } \\
18\end{array}$} & $\begin{array}{l}07.30- \\
09.15\end{array}$ & $\begin{array}{l}\text { Thoharoh (Tayamum, Istinja, Wudhu, } \\
\text { Mandi) }\end{array}$ & $\begin{array}{l}\text { Prof. Dr. H. Rosihon } \\
\text { Anwar, MA }\end{array}$ \\
\hline & $\begin{array}{l}09.30- \\
11.00\end{array}$ & $\begin{array}{l}\text { Salat Jama', Qoshor, Jenazah, } \\
\text { perjalanan,sujud tilawah }\end{array}$ & $\begin{array}{l}\text { Prof. Dr. H. Rosihon } \\
\text { Anwar, MA }\end{array}$ \\
\hline $\begin{array}{l}22-A p r- \\
18\end{array}$ & $\begin{array}{l}07.30- \\
11.00\end{array}$ & $\begin{array}{l}\text { Proses Perjalanan Ibadah Haji \& } \\
\text { Dinamika Kelompok (II) }\end{array}$ & $\begin{array}{l}\text { Dr. H. Ahmad Syamsir, } \\
\text { M.Si }\end{array}$ \\
\hline $\begin{array}{l}29-A p r- \\
18\end{array}$ & $\begin{array}{l}05.30- \\
11.00\end{array}$ & Praktek Lapangan haji & $\begin{array}{l}\text { Drs. H. Yusuf Abd. Kadir, } \\
\text { MM }\end{array}$ \\
\hline $\begin{array}{l}5 \text {-May- } \\
18\end{array}$ & $\begin{array}{l}09.30- \\
10.30\end{array}$ & OUTBOUND dan Munggahan & TEAM H. DODI \\
\hline $\begin{array}{l}20-\text { May- } \\
18\end{array}$ & $\begin{array}{l}09.00- \\
11.00\end{array}$ & $\begin{array}{l}\text { Pemantapan Bab Thaharah dan Shalat- } \\
\text { shalat }\end{array}$ & Drs. H. Dedi Mulyana \\
\hline \multirow{2}{*}{$\begin{array}{l}\text { 27-May- } \\
18\end{array}$} & $\begin{array}{l}07.30- \\
09.15\end{array}$ & Proses Perjalanan Ibadah Haji (III) & $\begin{array}{l}\text { Dr. H. Ahmad Syamsir, } \\
\text { M.Si }\end{array}$ \\
\hline & $\begin{array}{l}09.30- \\
11.00\end{array}$ & Proses Perjalanan Ibadah Haji (III) & $\begin{array}{l}\text { Dr. H. Ahmad Syamsir, } \\
\text { M.Si }\end{array}$ \\
\hline 3-Jun-18 & $\begin{array}{l}09.00- \\
11.00\end{array}$ & Kajian Islam Ramadhan 1439 H & $\begin{array}{l}\text { H. Nur Ihsan Jundullah, } \\
\text { Lc }\end{array}$ \\
\hline $\begin{array}{l}30-J u n- \\
18\end{array}$ & $\begin{array}{l}07.30- \\
11.30\end{array}$ & $\begin{array}{l}\text { PRAKTEK HAJI MASSAL DENGAN } \\
\text { KEMENAG }\end{array}$ & Pengurus \\
\hline 1-Jul-18 & $\begin{array}{l}09.00- \\
11.00\end{array}$ & $\begin{array}{l}\text { Bahasa Arab sehari-hari dan doa seputar } \\
\text { haji }\end{array}$ & $\begin{array}{l}\text { H. Furqon Baihaqi, S.Ag., } \\
\text { M.Pd.I }\end{array}$ \\
\hline 8-Jul-18 & $\begin{array}{l}07.00- \\
11.00\end{array}$ & $\begin{array}{l}\text { Informasi menjelang pemberangkatan dan } \\
\text { Review }\end{array}$ & $\begin{array}{l}\text { Dr. H. Ahmad Syamsir, } \\
\text { M.Si }\end{array}$ \\
\hline
\end{tabular}

(Sumber arsip KBIH Assyakur pada tanggal 25 Mei 2018).

Aplikasi bimbingan ibadah haji (di Tanah Suci). Kelompok bimbingan ibadah haji (KBIH) Assyakur setiap tahunnya mengirimkan perwakilan dari pengurus untuk menjadi pembimbing di Tanah Suci.

Aplikasi bimbingan di Tanah Air (pasca ibadah haji). Setelah melaksanakan ibadah haji, jamaah KBIH Assyakur juga selalu melakukan pengajian rutinan. Pengajian ini bertujuan untuk menjaga silaturrahim antar jamaah dan kepada pengurus. Pengajian ini biasanya diisi dengan mauidhoh dari salah satu pengurus KBIH Assyakur. Aplikasi perlengkapan haji.

KBIH Assyakur selain membantu jamaah dalam manasik juga membantu dalam hal perlengkapan haji, koperasi Assyakur menyediakan berbagai macam perlengkapan haji dan oleh-oleh haji. Semua jamaah KBIH bisa membeli perlengkapan haji seperti pakaian ihram dll. Selain itu para jamaah juga bisa 
memesan oleh-oleh haji dengan harga yang standar dan bisa langsung diantar dirumah. Jadi, pelaksanaan ibadah haji akan lebih khusuk tanpa memikirkan banyak hal dan tidak perlu repot di dalam pesawat karena membawa banyak barang.

Penerapan Fungsi Pengawasan. Pengawasan yang dilakukan KBIH Assyakur dilakukan dalam tiga tahap, yang pertama, setelah perekrutan jamaah seluruh pengurus mengadakan koordinasi dan evaluasi. Kedua, pengawasan dilakukan setelah pelaksanaan manasik haji. Ketiga, pengawasan dilakukan setelah pelaksanaan ibadah haji.

Manajemen sebagai seni dalam menyelesaikan pekerjaan melalui orang lain. Definsi ini mengandung arti bahwa para manajer mencapai tujuan-tujuan oraganisasi melalui pengaturan orang-orang lain untuk melaksanakan berbagai tugas yang mungkin diperlukan, atau berarti dengan tidak melakukan tugas-tugas itu sendiri. Definisi manajemen menurut Stoner dikutip dari (Handoko, 2009:8).

Manajemen merupakan usaha mencapai suatu tujuan tertentu melalui kegiatan orang lain. Dengan demikian manajer mengadakan koodinasi atas sejulah aktivitas orang lain yang meliputi perencanaan, pengorganisasian, penempatan, pengarahan, dan pengendalian. (Koontz, 1986:43)

Manajemen organisasi pada umumnya dikaitkan dengan aktivitas-aktivitas perencanaan, pengorganisasian, pengendalian, penempatan, pengarahan, pemotivasian, komunikasi dan pengambilan keputusan yang dilakukan oleh setiap organisasi dengan tujuan untuk mengkordinasikan berbagai sumber daya yang dimiliki oleh perusahaan sehingga akan dihasilkan suatu produk atau jasa secara efisien. (Kusnawan, 2017)

\section{Manajemen Promosi KBIH Asyyakur}

Dalam fungsi-fungsi manajemen yang terdiri dari planning (perencanaan), organising (pengorganisasian), actuating (penggerakan atau pelaksanaan), serta controlling (pengawasan) disebutkan bahwa promosi ditetapkan ketika proses planning (perencanaan). Seorang ketua KBIH melaksanakan fungsi-fungsi manajerial untuk mengetahui sasaran-sasaran yang dibutuhkan, tentang cara untuk mencapainya sebagaimana ditetapkan dalam perencanaannya. Tidak ada satupun lembaga atau organisasi dapat mencapai sukses tanpa ditunjang dengan perencanaan yang baik.

Perencanaan promosi dilakukan dengan disepakati para pengurus lembaga. apa yang akan digunakan diolah sedemikian rupa sehingga nantinya tidak akan menjadi sebuah penyebab kegagalan dalam pencapaian tujuan lembaga atau organisasi. yang digunakan sesuai dengan target yang akan dicapai maka akan berdampak baik dalam lembaga. Proses perencanaan sebuah lembaga, menetapkan berbagai keputusan diantaranya adalah bagaimana bisa 
mempromosikan sebuah lembaga tersebut di khalayak umum. Hal ini sangatlah penting karena tanpa adanya proses promosi, orang tidak akan tahu keberadaan lembaga tersebut. Ketika proses promosi sudah dilakukan, maka semakin banyak orang yang mengetahui adanya lembaga atau organisasi tersebut.

"Apa saja promosi yang dilakukan KBIH assyakur? Pada tahun pertama yaitu tahun 2000 awal berdiri, KBIH Assyakur tidak melakukan promosi karena banyak jamaah yang mendaftar dan juga belum banyaknya KBIH yang berdiri pada saat itu. Kemudian pada tahun-tahun berikutnya yaitu tahun 2001 sampai 2004 masih banyak juga yang mendaftar tetapi pada tahun 2005 mengalami penurunan jamaah yang mendaftar oleh karena itu $\mathrm{KBIH}$ Assyakur melakukan promosi dengan menggunakan membuat brosur, website, facebook, dan dari mulut ke mulut yang memanfaatkan alumni jamaah. (wawancara dengan H. Adang Nurdin pada 13 Maret 2018)".

Dari hasil wawancara promosi yang dilakukan KBIH Assyakur adalah dengan menggunakan brosur, media internet yaitu website media sosial yaitu facebook kemudian dari mulut ke mulut dengan memanfaatkan alumni yang merasa puas dengan seluruh kegiatan yang sudah pernah di diberikan oleh $\mathrm{KBIH}$,

Promosi tersebut ditentukan dalam perencanaan awal dan terprogram. Pada tahun $2000 \mathrm{KBIH}$ Assyakur tidak melakukan promosi oleh karena itu perencanaan promosi dilakukan pada tahun 2005 perencanaan promosi yang dilakukan oleh KBIH Assyakur adalah dengan membuat brosur, website, facebook, dan memanfaatkan alumni jamaah yang telah mengikuti bimbingan di KBIH Assyakur.

Advertising(Periklanan). Dalam melakukan promosi periklanan yang dilakukan oleh KBIH Assyakur adalah melalui brosur, webisite dan media sosial. agar dapat menarik minat para calon jamaah haji untuk ikut bimbingan di $\mathrm{KBIH}$ Assyakur.

"Pada tahun 2005 sampai sekarang KBIH Assyakur sudah melakukan Promosi serta membuat iklan melalui brosur, internet dan alumni, mengapa tindakan pertama langsung membuat promosi dengan itu semua? Karena pada tahun 2005 brosur dan internet sangat efektif dalam menjangkau para jamaah yang jauh serta iklan yang di sampaikan melalui brosur terlihat singkat dan menarik, serta dengan internet bisa menjangkau para calon jamaah yang lebih luas." (wawancara dengan H. Adang Nurdin pada 13 Maret 2018)".

Fungsi dari brosur, website dan media sosial ini adalah ketika ada calon jamaah haji yang daerahnya jauh dari lokasi maka calon jamaah haji tersebut bisa melihat serta mengetahui adanya KBIH Assyakur sehingga mereka akan mencoba mencari info lebih dalam lagi dan nantinya akan mendaftar di KBIH 
Assyakur. Hal-hal yang ditampilkan di brosur, webisite dan media sosial adalah sesuatu yang mudah difahami, menarik, serta mencantumkan keunggulankeunggulan yang dimiliki KBIH.

Tujuan pokok dari kebijaksanaan periklanan adalah memberikan informasi secara rutin tentang kegiatan-kegiatan perusahaan serta jasa-jasa yang tersedia. Hal ini diarahkan untuk pengenalan nama KBIH Assyakur kepada masyarakat luas. Kegiatan periklanan KBIH Assyakur dilakukan menggunakan beberapa media, diantaranya: media cetak brosur dan media sosial berupa Facebook.

Media Cetak (Brosur). KBIH Assyakur menggunakan media brosur untuk kegiatan periklanannya dengan tujuan menarik konsumen (calon jamaah) di lingkungan sekitar, dimana sasarannya adalah seluruh masyarakat Kota Bandung.

"Apakah KBIH Assyakur membagikan brosur ke tempat tempat tertentu, seperti masjid raya, supermarket atau tempat lainnya? Tentunya tidak Brosur KBIH Assyakur dibagikan ke tetangga jamaah-jamaah bimbingan tiap tahunnya, masyarakat yang dekat dengan lokasi KBIH mengapa karena Penyebaran Brsosur dilakukan oleh Seluruh Staf yang ada di KBIH Assyakur." (wawancara dengan Atep Yayat Hardiyatna pada 13 Maret 2018)".

Brosur disini digunakan oleh KBIH Assyakur dengan tujuan memberikan penjelasan dan pemahaman tentang produk dan layanan jasa yang ditawarkan oleh mereka. Dan juga sebagai alat pelengkap promosi karena media-media lain memiliki keterbatasan dalam hal menyampaikan atau waktu yang begitu singkat sehingga belum tentu konsumen memahami apa yang dijelaskan dalam media itu.

Media ini dirasa salah satu yang paling penting, yang mana pada sebuah brosur ini kita bisa memberiakan informasi tentang KBIH yang akan mudah dipahami dan di lihat oleh masyarakat luas. Di dalamnya bisa berupa informasiinformasi yang menggambarkan tentang $\mathrm{KBIH}$, informasi tentang produkproduk.

Dalam pelaksanaannya, memasarkan/menyebarkan brosur ini, yaitu dilakukan oleh semua elemen dari KBIH ini, baik itu ketua, sekretaris dan sebagainya. Biasanya brosur diberikan kepada masyarakat saat ada acara-acara terkait bimbingan, kemudian dari calon jamaah memberian ke tetangga nya, Demikian seterusnya.

Media Online (Website)

"Bagaimana ke efektifan promosi dengan website? Promosi dengan website cukup baik karena bisa memberikan banyak informasi mengenai $\mathrm{KBIH}$, mulai dari profil KBIH, Promo, Foto Kegiatan dan bisa diakses dengan mudah oleh para jamaah dan calon jamaah." (wawancara dengan H. Adang Nurdin pada 13 Maret 2018)”.

Pemanfaatan media internet sebagai media promosi juga digunakan oleh 
KBIH Assyakur, karena sifatnya yang mudah diakses oleh siapa saja dan dimana saja. Pertumbuhan pengguna internet yang sangat tinggi menjadikan internet cukup baik digunakan sebagai media untuk melakukan promosi. Website adalah salah satu media internet yang digunakan KBIH Assyakur untuk melakukan promosi. KBIH Assyakur memiliki official website, yang dapat diakses oleh jamaah, dan untuk mengunjungi official website KBIH Assyakur jamaah cukup membuka alamat website Yayasan Assyakur yaitu, www.assyakur.com informasi yang ditampilkan pada website tersebut cukup lengkakp seperti, profil, paket haji dan umrah, fasilitas, program, kontak, kegiatan-kegiatan perusahaan, dan lainlain.

Media Sosial (Facebook). KBIH Assyakur mempunyai sebuah akun facebook yang bernama "Yayasan Assyakur", https://www.facebook.com Lyayasan-assyakur akun ini selalu memberikan informasi yang terbaru tentang KBIH Assyakur. Biasanya sesuatu yang terkait kegiatan yang berkaitan dengan $\mathrm{KBIH}$, bisa berupa informasi promosi, dokumentasi berupa foto dan lain sebagainya.

"Mengapa KBIH assyakur memilih media sosial Facebook sedangkan masih banyak media sosial yang lain? Pada tahun 2014 awal dibuatnya akun Facebook KBIH Assyakur pada tahun ini facebook lagi ramai-ramai nya di pergunaakan oleh semua kalangan tidak terlepas dari banyaknya pengguna facebook ibu-ibu rumah tangga dan bapak-bapak sehingga $\mathrm{KBIH}$ berinisaitif membuat akun facebook agar mempermudah promosi dan menyesuaikan dengan zaman sekarang. (wawancara dengan Atep Yayat Hardiyatna pada 13 Maret 2018)".

Promosi dengan pemanfaatan jaringan internet tidak memerlukan banyak biaya serta dapat menghemat waktu dalam melakukan kegiatan promosinya. Melalui jaringan internet suatu informasi dapat disampaikan kepada konsumen secara langsung dan mudah untuk diakses kapan dan dimana saja. Dalam internet terdapat media sosial yang beraneka ragam berkembang saat ini, seperti media sosial Facebook yang sering digunakan dan dimiliki oleh para penguna internet.

Dalam hal ini KBIH Assyakur melakukan promosinya dengan melalui media sosial Facebook dengan memanfaatkan fitur Fanpage didalamnya. Dengan pemanfaatan fitur Fanpage salah satu keuntungannya adalah kemudahan dalam mengumpulkan fans atau penggemar hanya dengan menyukai halaman tersebut pada pilihan yang tertera dalam Fanpage tersebut. Salah satu yang menjadi keunggulan pada media sosial Fanpage yaitu para pengguna akun yang bukan anggota dalam Fanpage KBIH Assyakur dapat memberikan komentar pada kolom balasan secara langsung, selain itu pengguna akun yang bukan anggota Fanpage KBIH Assyakur dapat melihat segala bentuk informasi yang ada pada halaman Fanpage KBIH Assyakur yang bersifat umum. 
Promosi dengan pemanfaatan melalui media Fanpage dinilai memberi kemudahanan dalam penyampaian dan penerimaan segala informasi yang berkaitan dengan KBIH. Selain bahan informasi, postingan yang diunggah merupakan sebuah sarana pembelajaran bagi para calon jamaah dalam mengenal KBIH Assyakur. Dengan mengakses media sosial Facebook dan membuka fitur Fanpage KBIH Assyakur, maka pengguna dapat menerima informasi yang berkaitan dengan KBIH. Fanpage Facebook KBIH Assyakur pertama kali dibuat pada tahun 2014 oleh admin KBIH Assyakur dan mulai pertama kali dioperasikan hingga mulai ramai dikunjungi oleh konsumen sekitar pertengahan tahun 2015 silam.

Dengan memanfaatkan media sosial Facebook akan memiliki peluang yang besar dan menguntungkan dikarenakan Facebook merupakan media sosial yang memiliki pengguna terbanyak dari seluruh negara khususnya di negara Indonesia, dan memiliki kemudahan dalam mengaksesnya. Dengan demikian segala informasi terkait mengenai restoran dapat dengan mudah diakses bagi peselancar dunia maya pengguna media sosial Facebook.

Promosi dengan menggunakan media sosial memiliki banyak keuntungan, antara lain dari segi biaya tidak perlu mengeluarkan biaya untuk promosinya, kemudian berbagai kemudahan dalam mengakses segala informasi dan pengguna pun dapat mengakses informasi tersebut kapan saja dan dimana saja tanpa ada batasan ruang dan waktu.

Personal selling (Penjualan perorangan). Kegiatan personal selling yang dilakukan oleh KBIH Assyakur adalah dengan melakukan persentasi ke perusahaan atau lembaga. Kegiatan ini dilakukan dengan cara mengunjungi perusahaan atau lembaga tersebut oleh divisi marketing yang sudah diberi tugas sebelumnya. Dalam kegiatan tersebut tugas divisi marketing adalah menawarkan dan menjelaskan berbagai produk dan paket umrah yang dimiliki oleh KBIH Assyakur, harga setiap paket umrah, akomodasi serta transportasi yang akan diberikan, serta persyaratan yang harus di penuhi oleh calon jamaah. Persentasi yang dilakukan divisi marketing tidak hanya dengan membagikan brosur kepada calon jamaah, agar kegiatan persentasi lebih menarik dan bagus lagi persentasi dilakukan dengan menampilkan slide yang berisi materi-materi yang berkaitan dengan kegiatan ibadah umrah.

"Apa saja kegiatan Personal Selling yang dilakukan KBIH Assyakur? KBIH assyakur juga melakukan personal selling atau penjualan perorangan dimana dilakukan oleh staf yang ada di KBIH assyakur di kantor $\mathrm{KBIH}$, seperti memberikan pelayanan yang baik saat ada calon jaamaah yang mau mendaftar atau hanya sekedar bertanya tentang manasik yang ada di $\mathrm{KBIH}$ Assyakur, (wawancara dengan Atep Yayat Hardiyatna pada 25 Mei 2018). Ditambah menurut $H$. Adang Nurdin bahwa dengan adanya personal 
selling bisa meningkatkan kepercayaan dari para calon jamaah sehingga dengan adanya pelayanan yang baik jamaah yang akan mendaftar bisa mengajar teman-teman nya yang lain agar ikut mendaftar juga di KBIH dan terjadi promosi secara tidak langsung oleh caloon jamaah pendaftar.

Bentuk kegiatan personal selling yang dilakukan KBIH Assyakur selain melakukan persentasi di perusahaan atau lembaga, kegiatan ini sudah pasti dilakukan dikantor $\mathrm{KBIH}$ Assyakur sendiri. Dimana seluruh staff karyawan KBIH Assyakur dapat berperan sebagai penjual yaitu dengan memberikan pelayanan terbaik kepada jamaah yang datang ke kantor KBIH Assyakur baik jamaah yang akan mendaftar ataupu hanya untuk menanyakan program dan paket umrah yang tersedia di KBIH Assyakur. Sehingga tercipta kesan yang baik atas pelayanan yang diberikan oleh perusahaan. Dan biasanya jamaah yang datang memang sudah pernah menggunakan jasa KBIH Assyakur, jadi mereka datang ke kantor memang untuk mendaftar umrah kembali.

Personal selling dalam promis yang dilakukan oleh KBIH Assyakur yaitu melalui customer service di mana selain bertugas untuk melayani jamaah dari awal pendaftaran sampai pulang kembali ke Indonesia, customer service $\mathrm{KBIH}$ Assyakur juga mempunyai tugas untuk mempromosikan, memperkenalkan, serta merekomendasikan produk maupun jasa bimbingan ibadah umrah dan haji kepada jamaahnya.

Word of Mouth (Promosi dari mulut ke mulut). Strategi promosi dari mulut ke mulut (word of mouth) adalah pelanggan membicarakan mengenai suatu produk atau layanan jasa kepada keluarga dan kerabatnya. Sementara itu, perusahaan tidak perlu memasang anggaran iklan yang mengeluarkan biaya yang mahal dan banyak. Seorang jamaah haji yang dulu ketika mengikuti bimbingan jamaah haji merasa cocok dan senang dengan bimbingan haji yang diberikan oleh KBIH Assyakur, maka dia pun akan terus berusaha merekomendasikan kepada rekan dan saudaranya.

"Apalagi promosi yang dilakukan oleh KBIH Assyakur? Promosi yang dilakukan KBIH Assyakur dalam menarik jamaah haji supaya mendaftar adalah dengan memanfaatkan alumni jamaah haji yang telah mengikuti bimbingan di KBIH Assyakur dengan menyampaikan ke dari mulut ke mulut melalui pelayanan yang baik, (wawancara dengan H. Adang Nurdin pada tanggal 25 mei 2018)".

Oleh karena itu promosi mord of wouth pun bisa terjadi, meskipun jamaah tersebut pada saat ini sudah tidak mengikuti bimbingan lagi. Dengan memberikan pelayanan yang terbaik kepada setiap jamaah haji, maka memberikan kepuasan jamaah terbangun dari banyak faktor, salah satunya adalah pelayanan yang memuaskan. Pelayanan yang memuaskan meliputi: mendengar keluhan, menjalankan saran, memperbaiki kekurangan, menjaga hubungan baik dengan jamaah. 
"Dari promosi melalui brosur, website dan facebook, promosi yang mana yang paling effektif? Promosi yang paling effektif di KBIH Assyakur ini yaitu lewat mulut ke mulut karena jamaah merasa puas sehingga otomatis memberitahu kepada keluarga rekan-rekan untuk mendaftar di $\mathrm{KBIH}$ Assyakur.

Promosi word of mouth ini merupakan komunikasi yang paling efektif yang dilakukan KBIH Assyakur. Promosi ini dilakukan oleh para alumni-alumni jamaah yang merasa puas dengan pelayanan yang diberikan KBIH Assyakur setelah melakasanakan ibadah haji maupun umrah. Melalui word of mouth inilah KBIH Assyakur banyak dikenal.

Karena dirasa promosi online belum maksimal karena kurangnya tenaga SDM untuk mengolah promosi online tersebut. Dan promosi yang dirasa paling efektif yaitu melalui word of mouth, alam hal ini sudah jelas bahwa selama ini yang menjadikan KBIH Assyakur berkembang pesat adalah karena kualitas pelayanannya yang bagus. Komunikasi secara langsung kepada lawan bicara ternyata juga dapat memberikan keuntungan kepada KBIH Assyakur, karena pesan yang disampaikan langsung diterima oleh calon jamaah, keuntungan yang didapat dirasakan oleh jamaah, karena dengan menerima pesan langsung dari owner KBIH maka disitu akan terjalin sebuah hubungan yang saling menguntungkan antara satu sama lainnya. Aktifitas promosi ini bertujuan agar masyarakat ataupun calon jamaah tertarik untuk menggunakan jasa bimbingan ibadah haji yang ditawarkan oleh KBIH Assyakur.

"Siapa yang menjalankan promosi dari mulut ke mulut ini? Alumni KBIH Assyakur yang melaksanakan promosi ini, karena alumni kami kumpulkan dalam sebuah Group di media sosial yaitu facebook agar mudah bersilaturahim makanya alumni bagi KBIH Assyakur ini sebagai asset berharga bagi kami. (wawancara dengan H. Adang Nurdin pada tanggal 25 mei 2018)."

KBIH Assyakur yang memiliki fokus target promosi, sebab semakin banyaknya pesaing maka akan semakin kecil keberhasilan KBIH Assyakur, oleh karenannya fokus promosi KBIH Assyakur ialah melalui pelyanan alumni.

"jadi kenapa kita memilih sasaran alumni? Alumni itu kan sama saja dengan pelanggan kita, yang mana alumni disini menceritakan pengalaman mereka terhadap $\mathrm{KBIH}$ sehingga bagi komunikan juga tertarik oleh pengalaman mereka (pelanggan) yang didapat (wawancara dengan $\mathrm{H}$. Adang Nurdin pada tanggal 25 mei 2018)."

$\mathrm{KBIH}$ Assyakur berkomitmen akan fokus terhadap pelayanan alumni jamaah, Karena semakin banyaknya konsumen yang terpuaskan, semakin banyak pula konsumen yang tertarik untuk mendaftar haji di KBIH Assyakur. Hal ini ditinjau dari segi pengalaman alumni jamaah, sebelum sampai pada pengalaman 
konsumen, pihak KBIH Assyakur membangun sebuah pelayanan terhadap alumni, sehingga alumni diharapkan akan terpuaskan melalui pelayanan yang tersedia dari KBIH. Dari sebuah pelayanan akan beralih pada pengalaman konsumen, sehingga pelanggan atau alumni dapat menceritakan pengalaman yang didapat dari KBIH Assyakur terhadap orang lain, dari sinilah konsumen baru atau calon jamaah tertarik akan KBIH Assyakur dikarenakan bukti nyata, yaitu pengalaman alumni sudah ada. Selain itu banyak juga upaya yang menguntungkan KBIH Assyakur dengan cara memelihara kepercayaan alumni daripada melakukan pemasaran yang lainnya.

Oleh karenannya KBIH Assyakur memfokuskan pelayanan terhadap alumni yang mana pelayanan alumni lebih memberikan kontribusi yang menjanjikan. Selain itu, pemasaran melalui pelayanan alumni ini juga dapat menjadi jangka panjang bagi KBIH Assyakur, sehingga ini sama dengan halnya investasi yang mana jika tidak untuk dikonsumsi di masa ini, maka akan di konsumsi dimasa yang akan dating Bahkan KBIH Assyakur menganggap semua alumni yang berasal darinya ialah bentuk daripada keluarga.

Hubungan harmonis sangat dipedulikan KBIH Assyakur, ini diyakini bahwa sebuah hubungan keluarga akan bertahan lebih lama dibandingkan dengan hubungan rekan bisnis. Maksud daripada keluarga disini ialah, sebuah komitmen bersama antara pihak KBIH Assyakur dan para alumni sebagai keluarga yang dibentuk untuk sama-sama berjalan di jalan Allah SWT. Pihak karyawan KBIH Assyakur dan alumni sangatlah dekat terhadap alumni sehingga batasan antara alumni dan karyawan hampir tidak ada dikarenakan semuanya berbaur dan dianggap sama dalam sebuah hubungan keluarga.

manajemen promosi merupakan kegiatan untuk mengarahkan serta membimbing dalam kegiatan memperkenalkan produk, meyakinkan dan mengingatkan kembali manfaat produk tersebut kepada konsumen dengan harapan mereka terjebak hatinya dengan sukarela menjadi mitranya (Sutoyo, 1981: 24).

Sedangkan Philip mendefinisikan manajemen promosi sebagai penganalisaan, pelaksanaan dan pengawasan program-program yang ditujukan untuk menarik sebagai mitra dengan untuk mencapai tujuan organisasi (Kotler, 1996: 38).

Promosi pada hakekatnya adalah suatu komunikasi pemasaran, artinya aktifitas pemasaran yang berusaha menyebarkan informasi, mempengaruhi, membujuk, dan atau mengingatkan pasar sasaran atas perusahaan dan produknya agar bersedia menerima, membeli dan loyal pada produk yang ditawarkan perusahaan yang bersangkutan (Tjiptono, 2008:20). 


\section{PENUTUP}

Berdasarkan hasil penelitian baik melalui observasi, dokumentasi serta melalui serangkaian wawancara dan dilanjutkan dengan proses analisis sedemikian rupa akhirnya dapat disimpulkan sebagai berikut:

Pertama, manajemen promosi yang digunakan KBIH Assyakur dalam upaya mempromosikan produk dengan memberikan jasa pelayanan dan bimbingan. Diperoleh hasil bahwa KBIH Assyakur mempraktikkan teori elemen bauran promosi sesuai teori yang ada, namun tidak semua media digunakan, hanya beberapa yaitu yang pertama, periklanan, dengan Media Cetak (Brosur), Media Internet (Website), Media Sosial (Facebook). Kedua melalui Penjualan perorangan dimana seluruh pengurus KBIH Assyakur dapat berperan sebagai penjual yaitu dengan memberikan pelayanan terbaik kepada jamaah yang datang ke kantor KBIH Assyakur baik jamaah yang akan mendaftar ataupun hanya untuk menanyakan program dan paket umrah yang tersedia di KBIH Assyakur. Ketiga promosi dari Mulut ke Mulut yang dilakukan oleh alumni-alumni yang sudah pernah dibimbing di KBIH Assyakur.

Kedua, secara keseluruhan implementasi Manajemen Promosi yang dilakukan KBIH Assyakur sangat effektif dan efisien terutama promosi dari mulut ke mulut promosi ini bisa dengan cepat menarik minat jamaah haji untuk mendaftar ke KBIH Assyakur karena dilakukan oleh para alumni-alumni jamaah yang merasa puas dengan pelayanan yang di berikan oleh KBIH Assyakur walaupun implementasi dari manajemen promosi yang dilakukan $\mathrm{KBIH}$ masih adanya penurunan jumlah jamaah haji.

Dari pembahasan serta kesimpulan yang ada maka penulis dapat memberikan masukan atau saran kepada KBIH Assyakur yaitu sebagai berikut: Pertama, hendaknya promosi yang dilakukan KBIH Assyakur saat ini jangan hanya mengandalkan promosi dari mulut ke mulut saja tapi juga memaksilmalkan penggunaan media internet website dan facebook karena masih kurang menarik baik dari konten maupun isi dengan demikian KBIH Assyakur bisa lebih banyak menumbuhkan minat jamaah haji untuk mendaftar di KBIH Assyakur.

Kedua, berdasarkan data, promosi melalui media bagi KBIH Assyakur tidak begitu penting dalam usaha meningkatkan jumlah jemaah. Akan tetapi pada tahun-tahun berikutnya KBIH Assyakur tetap melakukan promosi melalui media.

Ketiga, sebaiknya KBIH Assyakur melakukan kegiatan pemberian hadiah yang menarik kepada jemaah selain buku panduan, buku kenang-kenangan dan lainlain.

\section{DAFTAR PUSTAKA}

Aziz, A. \& Kustini. (2007). Ibadah Haji Dalam Sorotan Publik. Jakarta: Puslitbang 
Kehidupan Keagamaan.

Handoko, T. H.. (2009). Manajemen. Cetakan Duapuluh, Yogyakarta: Penerbit BPEE

Jogiyanto, (2007). Sistem Informasi Keperilakuan. Edisi Revisi. Yogyakarta: Andi Offset

Kusnawan, A., Rahman, A., Lukman, D., \& Dulwahab, E. (2017). Manajemen

Mutu Input Kelompok Bimbingan Ibadah Haji Indonesia. Ilmu Dakwah:

Academic Journal for Homiletic Studies, 11(2), 277-292.

Kotler, P. (1996). Manajemen Pemasaran. diterjemahkan oleh Benyamin Molan.

Edisi 11, Jilid 1. Jakarja: PT Indek Kelompok Gramedia.

Koontz, H. \& Cyril, O’D. \& Heinz, W. (1986). Manajemen. Jilid 2.

Nidjam, A. \& Alatief, H. (2004), Manajemen Haji. Jakarta: Zikrul Hakim.

Slameto, (2003). Belajar dan Faktor-Faktor Yang Mempengarubinya Jakarta: Rineka Cipta

Sutoyo, S. (1981). Kerangka Dasar Manajemen Pemasaran. Jakarta: PT Dharma Aksara.

Saraswati. (2013). Faktor Minat Perilaku Menggunakan Sistem Informasi Akuntansi

Berbasis E-Commerce. Simposium Nasional Akuntansi XVI.

Tjiptono, F. (2008). Strategi Pemasaran Edisi 3. Yogyakarta: ANDI 